\title{
Protective Value of Gamma Globulin Preparations against Group B Streptococcal Infections in Chick Embryos and Mice
}

\author{
LAWRENCE C. VOGEL, ROBERTO R. KRETSCHMER, DONNA M. PADNOS. PEGGY D. KELLY. \\ AND SAMUEL P. GOTOFF $F^{2+41}$ \\ Department of Pediatrics, Michael Reese Hospital and Medical Center, Chicago, Illinois, USA
}

\begin{abstract}
Summary
The protective value of pooled human gamma globulin (GG) and a group B streptococcal immune globulin (GBSIG) was studied in a chick embryo and a murine model of group B streptococcal (GBS) infection. Chick embryos were protected by the IV administration of 0.4 to $0.8 \mathrm{mg}$ of GG from three manufacturers against IV challenge with type Ia GBS. Two of three GG preparations at doses of 0.4 to $1.65 \mathrm{mg}$ protected chick embryos against type III, but $1.65 \mathrm{mg}$ of all three preparations failed to protect against GBS types Ib and II. Mice were protected from lethal IP challenges with types Ia and Ib by the prior IM inoculation of three and two of the three GG preparations at doses of 0.5 to $1.0 \mathrm{mg}$, respectively. Administration IM of $1 \mathrm{mg}$ of GG failed to protect mice against types II and III.

The IV administration of $0.2 \mathrm{mg}$ of GBSIG protected chick embryos against IV inoculation with GBS types Ia, Ib, II, and III. Administration IM of $0.5 \mathrm{mg}$ of GBSIG protected mice against IP challenges with types Ia, Ib, and II, but not with type III. The IP administration of $0.25 \mathrm{mg}$ of GBSIG simultaneously with type III GBS protected mice, whereas GG was not protective. GBSIG should undergo clinical trials for the prevention of GBS infections and their recurrences and as a possible adjunct to antibiotic and supportive therapy of severe GBS infections.
\end{abstract}

\section{Speculation}

Some human sera contain antibody which protects animals against infection with group B streptococcus. If passive immunization with human gamma globulin or group B streptococcal immune globulin is effective in animal models, it may be potentially useful in preventing neonatal group $B$ streptococcal infections. and clinical trials would be indicated.

Group B streptococci (GBS) are major bacterial pathogens in early infancy (1). Despite appropriate antimicrobial therapy, neonatal GBS infections are associated with a high morbidity and mortality, suggesting that efforts be directed toward prevention of these infections by active or passive immunoprophylaxis (9). One predisposing factor in the development of neonatal GBS infections is low concentrations of maternal transplacentally acquired, typespecific antibody $(3,4,7,21)$. Therefore, active immunization of women of childbearing age would be an ideal approach in preventing neonatal GBS infections. Baker et al. (2) have described a native type III carbohydrate antigen as a potential vaccine, and preliminary studies in adult volunteers have shown that this vaccine is immunogenic and safe.

Until vaccines for each of the five GBS types have been developed and administered to the susceptible childbearing population, passive immunization might be used to prevent neonatal GBS infections. Hyperimmune and pooled human gamma globulin $(G G)$ have been used with variable success in the prophylaxis and treatment of several viral and bacterial infections (17). Passi immunization of pregnant women or newborn infants might pri vide protection to the infant during the first few months of life. 1 addition, passive immunization might be effective in preventin recurrent GBS infections and may be a useful adjunct to antibiot therapy.

Stewardson-Krieger et al. (15) have demonstrated that poole GG at a dose as low as $0.3 \mathrm{ml} / \mathrm{kg}$ IM protected mice from leth IP challenges with type Ia GBS. These investigations have bee extended to include GG from three different manufacturers an passive protection studies in both mice and chick embryos usin GBS types Ia, Ib, II, and III. Protection studies in mice and chic embryos were also performed using a group B streptococci immune globulin (GBSIG), which was prepared from human ser with high titers of type-specific IgG antibody.

\section{MATERIALS AND METHODS}

PREPARATION OF BACTERIA

GBS Ia-SS615 (type Ia) was obtained from the Center for Disease Control and was passed 28 times in adult mice anc designated Ia-SS615/28 (11). Mouse-passaged strains Ib-H36B $60 / 2$ (type Ib) and II-18RS21/67/1 (type II) were kindly suppliec by Dr. Rebecca Lancefield. GBS Ib-Grav, III-And. III-Bell. IIIDaw, III-Grif, and III-Heat were isolated from infants with GBS infections.

Bacteria were grown at $37^{\circ} \mathrm{C}$ to midlogarithmic phase (optical density of 0.30 at $550 \mathrm{~nm}$ ) in Todd-Hewitt broth containing $0.5 \%$ dextrose. Aliquots were frozen in an acetone:dry ice bath and stored at $-70^{\circ} \mathrm{C}$ until used. Viability and concentrations of bacteria $(\mathrm{cfu} / \mathrm{ml})$ were determined for each experiment by spread plating on trypticase soy:5\% defibrinated sheep blood agar plates

\section{COLLECTION AND PREPARATION OF TEST SERA}

Pooled $16.5 \%$ human GG was obtained from three manufacturers: Cutter Laboratories, Inc., Berkeley, CA (lot M6352): Hyland Laboratories, Division of Travenol Laboratories. Inc.. Costa Mesa, CA (lot 0442D011AA); and Armour Pharmaceutical Co. Phoenix, AZ (lot R 16804). To remove IgG aggregates prior to IV injection into chick embryos. GG was centrifuged at $30.000 \mathrm{rpm}$ for $3 \mathrm{hr}$ at $4^{\circ} \mathrm{C}$ and sterilized by passage through Millipore filters with $0.45-\mu \mathrm{m}$ pores.

Hyperimmune rabbit anti-GBS type III sera were prepared by immunizing adult male New Zealand White rabbits IV with a formalinized whole cell vaccine of III-Bell (11). Human sera used in passive protection studies in mice were obtained from healthy women and were frozen in $1-\mathrm{ml}$ aliquots at $-70^{\circ} \mathrm{C}$ until used. The human sera were heat inactivated at $56^{\circ} \mathrm{C}$ for $30 \mathrm{~min}$ before use.

The GBSIG was prepared by pooling human sera from five adult volunteer blood donors with high titers of antibody against GBS serotypes. Each of the sera had type-specific IgG antibody 
easured by an indirect immunofluorescent (IF) assay to at least 1e of the GBS serotypes and had titers that were at least twice e minimum titer required for chick embryo protection (21). The ra were pooled in equal amounts, and the $\operatorname{IgG}$ fraction was tained by $\left(\mathrm{NH}_{4}\right)_{2} \mathrm{SO}_{4}$ precipitation and DEAE-cellulose chroatography (8). Using membrane filtration (CF50A membrane ines: Amicon Corp., Lexington, MA), the GBSIG was concenated to a protein concentration of $1105 \mathrm{~g} / 100 \mathrm{ml}$ as determined $y$ the Biuret reaction. Purity of GBSIG was demonstrated by amunoelectrophoresis.

\section{INDIRECT IMMUNOFLUORESC ENT TEST}

The IF assay for type-specific $\operatorname{IgG}$ antibody to each of the GBS :rotypes utilizes acetone-fixed whole bacteria on slides and monosecific rabbit antihuman $\mathrm{IgG}$ conjugated with fluorescein isothisyanate $(21)$.

\section{ANIMAL STUDIES}

Twelve-day-old chick embryos were inoculated IV with $0.1 \mathrm{ml}$ f a mixture containing equal volumes of a lethal inoculum of iBS diluted in phosphate-buffered saline. $\mathrm{pH} 7.2$ (PBS) and GG r GBSIG (18). The $50 \%$ lethal dose $\left(\operatorname{LD}_{5 x}\right)$ and $90 \%$ lethal dose LD(स) for Ia-SS615/28, Ib-H36B/60/2. II-18RS2I/67/1, and IIIiell have been reported previously $(18,21)$. The $L D_{(x)}$ and $L D_{\{n}$ f III-And. III-Daw, III-Grif, and III-Heat were determined by robit analysis of dose mortality curves established by IV inoculaon of chick embryos with increasing numbers of bacteria in 0.1 1l. The inoculum of GBS used in passive protection studies in hick embryos was one to two times the LD!n). GG was diluted I/ $1 / 10,1 / 20$, and $1 / 40$ with $\mathrm{PBS}$. which resulted in the inoculation f $1.65,0.8,0.4$, and $0.2 \mathrm{mg}$ of $\mathrm{GG}$ into chick embryos, respecively. The GBSIG was diluted with PBS so that the amount njected was $0.4 .0 .2,0.1,0.05$, and $0.025 \mathrm{mg}$.

The bacterial inoculum that consistently produced greater than ( $)$ mortality in 21 -day-old mice was established by IP injection if increasing numbers of Ib-Grav, Ib-H36B/60/2, and II-18RS2I/ $.7 / 1$ in $0.2 \mathrm{ml}$ of PBS. III-Bell, and III-Daw in $1.0 \mathrm{ml}$ of heart nfusion (HI) broth with $5 \%$ defibrinated sheep blood (5). Passive rotection studies in 21-day-old mice challenged with Ia-SS615/ :8 have been described previously (15). Mice received 0.25 to 1 $\mathrm{mg}$ of GG or 0.03 to $4.8 \mathrm{mg}$ of GBSIG in $0.1 \mathrm{ml}, 0.1$ to $0.5 \mathrm{ml}$ of human serum, or $0.05 \mathrm{ml}$ of rabbit anti-III serum IM $24 \mathrm{hr}$ prior to lethal IP challenge with GBS. Inocula that consistently produced greater than $90 \%$ mortality were used. Protection studies in mice with III-Bell were also performed inoculating $0.2 \mathrm{ml}$ of undiluted human sera or $0.125 \mathrm{mg}$ to $1 \mathrm{mg}$ of GG or GBSIG IP simultaneously with the IP challenge with III-Bell. Deaths were monitored for three days after the bacterial challenge.

At least four chick embryos or mice were given injections of each dilution of GG or human sera and type of GBS tested. The mean number of chick embryos tested per dilution of GG for each of the GBS types was 8 , and the mean number of mice tested was 6.5. Protection was designated if at least $75 \%$ of chick embryos or mice survived the bacterial challenge. Controls for each experiment included injection of PBS, bacteria, GG, and protective or nonprotective human sera with bacteria.

\section{RESULTS}

The $L D_{5 k}$ and $L_{(k)}$ in 12-day-old chick embryos for the type III GBS strains, III-And. III-Daw, III-Grif, and 11I-Heat, are shown in Table 1 . Susceptibility of 21 -day-old mice to IP challenge with GBS Ib-Grav, Ib-H36B/60/2, II-18RS21/67/1, III-Bell, and III-Daw is shown in Table 2.

The minimal amount of GG or GBSIG necessary to protect chick embryos against GBS types Ia. Ib, II, and III is shown in Table 3. Protection studies were not performed with type Ic GBS because of our previous finding that protection of chick embryos by human sera is nearly identical for types Ia and Ic (21). Chick embryos were protected against IV challenges with type Ia-SS615/ 28 by the simultaneous IV administration of all three $G G$ preparations at doses of 0.4 to $0.8 \mathrm{mg}$. For types $\mathrm{Ib}-\mathrm{H} 36 \mathrm{~B} / 60 / 2$ and II18RS21/67/1, $1.65 \mathrm{mg}$ of all three GG preparations failed to protect chick embryos. GG from two of three manufacturers protected chick embryos against type III-Bell at doses of 0.4 and $1.65 \mathrm{mg}$.

Mice inoculated IP with type la GBS were protected by the IM administration of 0.5 to $1.0 \mathrm{mg}$ of all three $G \mathrm{G}$ preparations (Table 4). For type Ib-H36B/60/2, mice were protected by two of three GG preparations given IM at doses of 0.5 and $1.0 \mathrm{mg}$. Because the $L D_{: * 1}$ of $\mathrm{Ib}-\mathrm{H} 36 \mathrm{~B} / 60 / 2$ inoculated IP into mice was

Table 1. Susceptibility of 12-day-old chick embryos to type III GBS

\begin{tabular}{|c|c|c|c|c|c|}
\hline \multirow[b]{2}{*}{ cfu injected } & \multicolumn{3}{|c|}{ Table 1. Susceptibility of 12-day-old chick embryos to type III GBS } & \multirow{2}{*}{\multicolumn{2}{|c|}{$\begin{array}{c}\text { III-Heat } \\
\text { (dead/injected }\end{array}$}} \\
\hline & $\begin{array}{c}\text { Ill-And } \\
\text { (dead/injected) }\end{array}$ & $\begin{array}{c}\text { III-Daw } \\
\text { (dead/injected) }\end{array}$ & $\begin{array}{c}\text { III-Grif } \\
\text { (dead/injected) }\end{array}$ & & \\
\hline 5.25 & $0 / 4 \quad(0)^{1}$ & $11 / 22 \quad(50)$ & $9 / 16 \quad(56)$ & & $3 / 9 \quad(33)$ \\
\hline 26.50 & $11 / 22$ & $16 / 26 \quad(62)$ & $12 / 20 \quad(60)$ & & $9 / 11 \quad(82)$ \\
\hline $51-100$ & $8 / 18 \quad(44)$ & $39 / 46 \quad(85)$ & $9 / 12 \quad(75)$ & & $\mathrm{ND}^{2}$ \\
\hline $101-150$ & $4 / 4 \quad(100)$ & $8 / 8 \quad(100)$ & $4 / 4(100)$ & & $4 / 4 \quad(100)$ \\
\hline $151 \ldots 2(x)$ & $4 / 4(100)$ & ND & $4 / 4 \quad(100)$ & & $4 / 4(100)$ \\
\hline $\mathrm{LD})_{\ldots+1}$ & 41 cfu & $18 \mathrm{cfu}$ & $24 \mathrm{cfu}$ & & $19 \mathrm{cfu}$ \\
\hline LD $D_{: n 1}$ & $187 \mathrm{cfu}$ & 120 cfu & $106 \mathrm{cfu}$ & & 59 cfu \\
\hline
\end{tabular}

'Numbers in parentheses, "r mortality

ND, not done.

Table 2. Susceptibility of 21-day-old mice to GBS

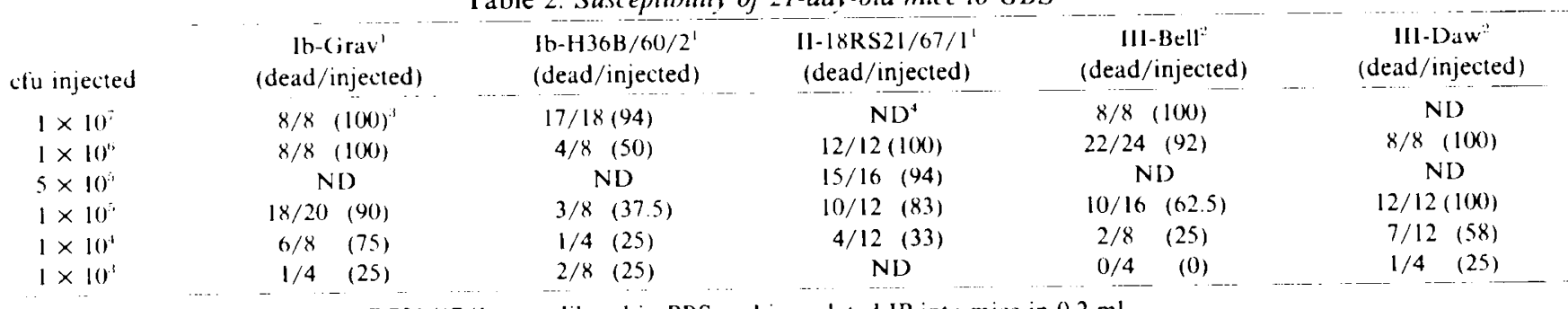

Ih-Grav, Ib-1136B/60/2, and II-18RS21/67/I were diluted in PBS and inoculated IP into mice in $0.2 \mathrm{ml}$.

III-Bell and III-Daw were diluted in $\mathrm{HI}$ broth with sheep red blood cells and inoculated IP into mice in $1.0 \mathrm{ml}$.

"Numbers in parentheses," mortality.

ND). not done. 
large, Ib-Grav, with a smaller $\mathrm{LD}_{(\%)}$, was also used in mouse protection studies, and GG from only one manufacturer protected mice at a dose of $1 \mathrm{mg}$. For II-18RS21/67/1, none of the GG preparations protected mice. Using IP inoculations of III-Bell or III-Daw in $1 \mathrm{ml}$ of $\mathrm{HI}$ broth with sheep blood, IM administration of $1 \mathrm{mg}$ of any of the three GG preparations failed to protect mice.

In mice challenged IP with a lethal dose of III-Bell in I $\mathrm{ml}$ of $\mathrm{HI}$ broth with sheep blood, simultaneous IP administration of 0.2 $\mathrm{ml}$ of human sera with IF titers of 1:80 or greater protected mice.
However, none of the GG preparations inoculated IP at a dose । I mg protected mice against simultaneous IP challenge with II Bell.

Because none of the three GG preparations protected mice ، chick embryos against all four GBS serotypes tested. a GBSI was prepared from selected immune human donors. Table 5 shou the antibody titers by IF to each of the GBS types, each of th five constituent human sera. GBSIG, and in the GG preparation Administration IV of $0.2 \mathrm{mg}$ of GBSIG protected chick embryc

Table 3. Passive protection of chick embryos with $G G$ and $G B S I G$

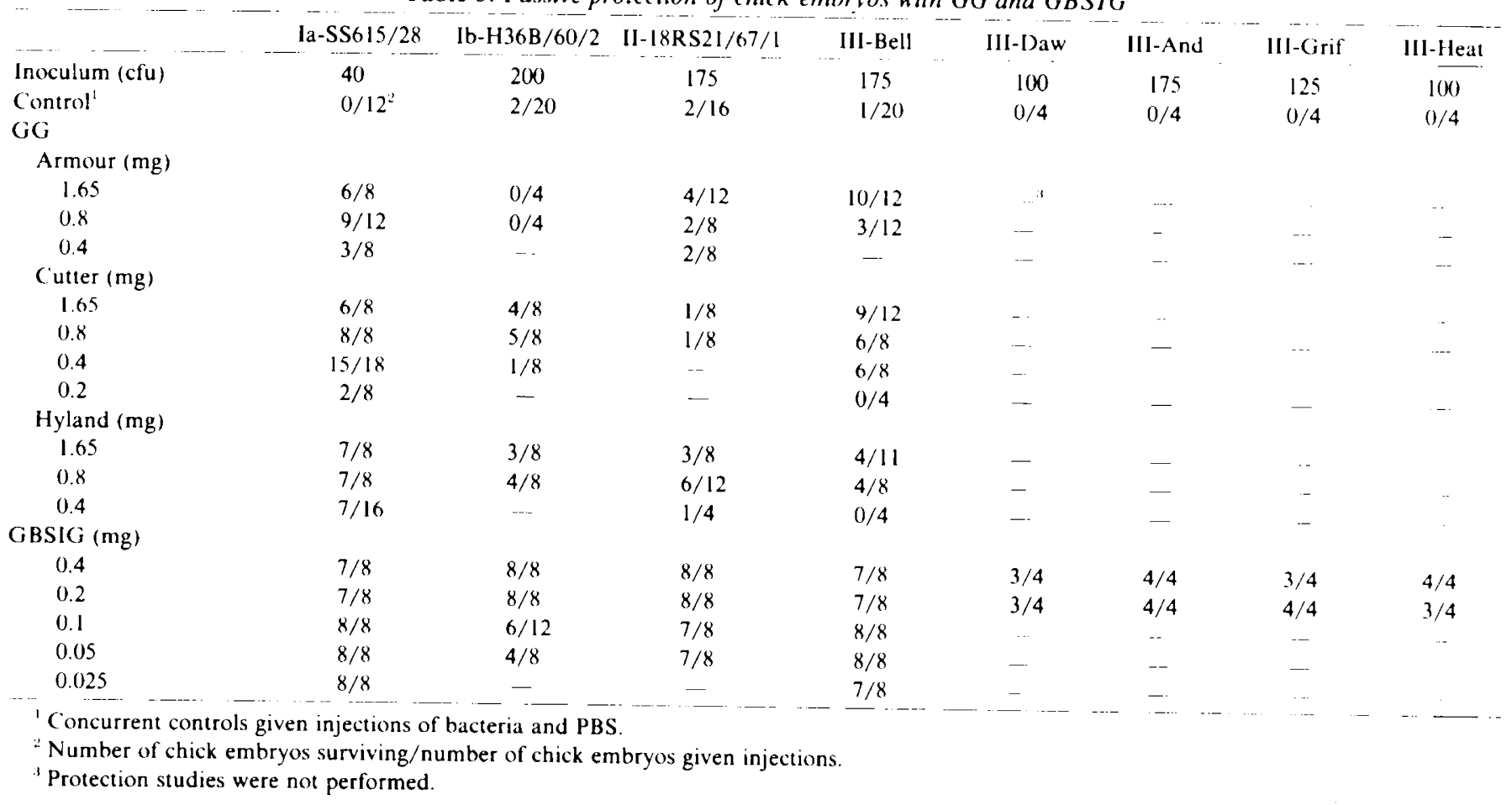

Table 4. Passive protection of mice with $G G$ and $G B S I G$

\begin{tabular}{|c|c|c|c|c|c|c|c|}
\hline 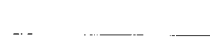 & Ia-SS615/28 & $\mathrm{Ib}-\mathrm{H} 36 \mathrm{~B} / 60 / 2$ & Ib-Grav & $11-18 \mathrm{RS} 21 / 67 / 1$ & III-Bell & III-Daw & III-Bell (IP)' \\
\hline Inoculum (cfu) & $2 \times 10^{3}$ & $1 \times 10^{7}$ & $1 \times 10^{5}$ & $5 \times 10^{5}$ & $1 \times 10^{15}$ & $1 \times 10^{6}$ & $1 \times 10^{6 i}$ \\
\hline Control $^{2}$ & $1 / 16^{3}$ & $2 / 16$ & $1 / 12$ & $2 / 20$ & $1 / 16$ & $0 / 8$ & $1 / 12$ \\
\hline $\begin{array}{l}\text { Armour (mg) } \\
\quad 1.0\end{array}$ & -4 & $4 / 8$ & $4 / 8$ & \multirow{2}{*}{$0 / 8$} & & & \\
\hline 0.5 & $7 / 8$ & $1 / 4$ & - & & $3 / 16$ & \multirow[t]{2}{*}{$0 / 5$} & $\begin{array}{l}1 / 4 \\
0 / 4\end{array}$ \\
\hline 0.25 & $1 / 4$ & - & .- & - & $-\overline{-}$ & & $0 / 4$ \\
\hline \multicolumn{8}{|l|}{ Cutter (mg) } \\
\hline 1.0 & - & $4 / 4$ & $4 / 4$ & $7 / 12$ & $2 / 8$ & $0 / 5$ & $1 / 4$ \\
\hline 0.5 & $6 / 8$ & $7 / 8$ & $4 / 8$ & $0 / 4$ & & -- & $1 / 4$ \\
\hline 025 & $0 / 4$ & $1 / 8$ & $\cdots$ & - & - & - & $1 / 4$ \\
\hline \multicolumn{8}{|l|}{ Hyland (mg) } \\
\hline 1.0 & $4 / 4$ & $6 / 8$ & $3 / 8$ & $3 / 8$ & $2 / 11$ & $1 / 4$ & $1 / 4$ \\
\hline 0.5 & $3 / 8$ & $4 / 8$ & - & .. & - & -- & $1 / 4$ \\
\hline 0.25 & - & -- & -- & & - & & \\
\hline \multicolumn{8}{|l|}{$\begin{array}{l}\text { GBSIG (mg) } \\
4.8\end{array}$} \\
\hline 4.8 & - & - & - & -- & $1 / 8$ & - & \\
\hline 1.0 & & $4 / 4$ & - & $4 / 4$ & $5 / 20$ & $4 / 8$ & \\
\hline 0.5 & $4 / 4$ & $4 / 4$ & $4 / 4$ & $4 / 4$ & - & & $4 / 4$ \\
\hline 0.25 & $4 / 4$ & $4 / 8$ & $8 / 8$ & $4 / 4$ & -... & & $6 / 8$ \\
\hline 0.12 & $4 / 4$ & -- & $7 / 8$ & $0 / 8$ & & - & $0 / 4$ \\
\hline 0.06 & $7 / 8$ & - & $5 / 8$ & $1 / 8$ & - & $\cdots$ & -- \\
\hline 0.03 & $7 / 8$ & - & - & $0 / 4$ &.- & 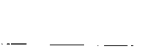 & $\ldots$ \\
\hline
\end{tabular}

${ }^{1}$ Mice inoculated IP simultaneously with III-Bell and GG.

2 Concurrent controls given injections of bacteria and PBS.

${ }^{3}$ Number of mice surviving/number of mice given injections.

${ }^{4}$ Protection studies were not performed. 
Table 5. Antibody titers of GBSIG constituent human sera, and pooled $G G$

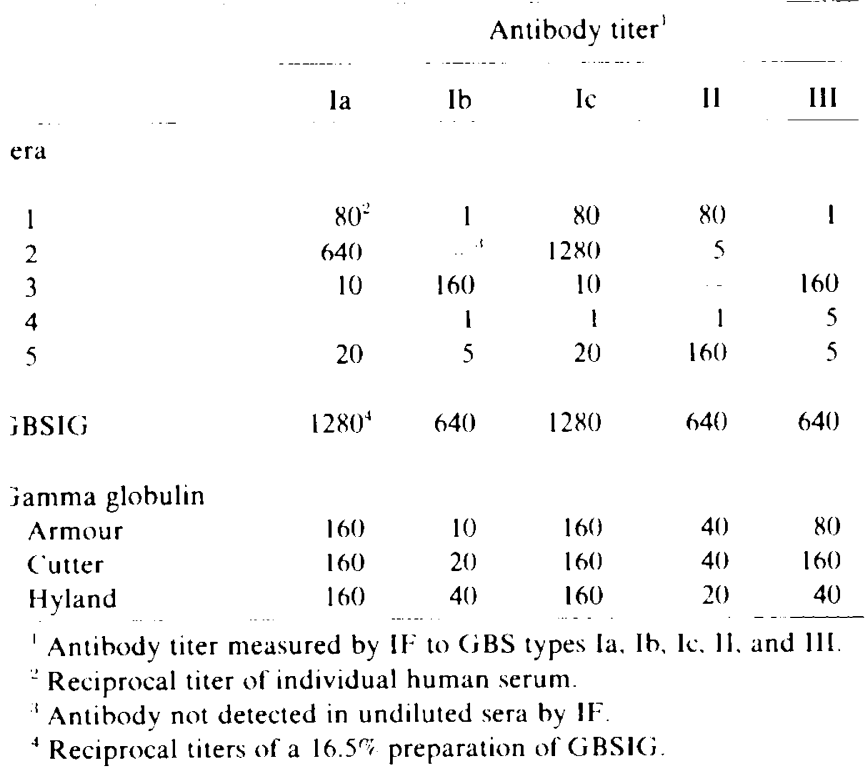

gainst lethal IV challenges with all strains of the four GBS types ested.

The IM administration of GBSIG protected mice against IP hallenges with types Ia, Ib, and II GBS strains at doses from 0.03 ว $0.5 \mathrm{mg}$. As much as $4.8 \mathrm{mg}$ of GBSIG administered IM failed o protect mice challenged IP with III-Bell. The IM administration ff up to $0.5 \mathrm{ml}$ of a human serum with an IF antibody titer to ype III of 1:640 also failed to protect mice against IP challenge vith III-Bell, with four of eight mice surviving. In contrast. 0.05 $\mathrm{nl}$ of hyperimmune rabbit anti-III serum administered IM proected all four mice against subsequent IP challenge with III-Bell. astly, the simultaneous administration of $0.25 \mathrm{mg}$ of GBSIG vith III-Bell IP protected all four mice tested.

\section{DISCUSSION}

Until an effective and safe vaccine is developed and distributed or all five GBS types, passive immunization could be a useful lternative for the prevention of neonatal GBS infections. Earlyinset GBS infections could be prevented by the administration of jG to mothers or neonates in pregnancies associated with a high isk of neonatal GBS infections (1, 16). Because early-onset GBS $\mathrm{nfections}$ are often acquired in utero $(1,16)$, administration of JG to the mother prior to or during labor may be useful in reventing or attenuating these infections. Alternatively, passive mmunization could be given at birth to neonates who are at high isk of developing early-onset GBS infections. Because recurrent JBS infections in neonates have been a problem $(6,19,22)$. sassive immunization may be worthwhile in preventing recurences after completion of antimicrobial therapy. Passive immuization may also be of value in the prevention of late-onset $\mathrm{GBS}$ nfections in colonized infants who lack protective levels of typeipecific antibody.

Despite appropriate antibiotics, the mortality of early-onset JBS infections is approximately $50 \%$ (1). Shigeoka et al. (14) have presented preliminary data suggesting benefit from transfusing infants with fresh whole blood containing heat-stable, type-spesific opsonins in the therapy of early-onset GBS infections. All nine neonates who received blood containing antibody to their infecting strains survived, but only three of six infants survived who were transfused with blood lacking homologous type-specific antibody. An increase of type-specific opsonic activity was only observed in neonates who received a transfusion of at least $40 \%$ of their blood volume. Similarly, GG could also be used as an adjunct to antibiotic and supportive therapy in GBS infections.
The advantages include administration to small neonates in acceptable volumes, thus avoiding transfusion, and a defined antibody content.

We have evaluated prophylactic GG and GBSIG in two experimental animal models of GBS infection. GG from each of three manufacturers failed to uniformly protect chick embryos or mice against lethal infections with all of the four GBS types tested. This result was not surprising because we have found that only a small percentage of sera from adults possess type-specific $\lg G$ antibody which protects chick embryos (20). Therefore. GBSIG was prepared from selected immune donors.

The simultaneous IV inoculation of GBSIG with GBS-protected chick embryos against all strains of the four GBS types tested. To estimate the amount of GBSIG in a human neonate that is equivalent to the protective dose of GBSIG in the chick embryo, we assumed blood volumes of $1.5 \mathrm{ml}$ in 12-day-old chick embryos (13) and $85 \mathrm{ml} / \mathrm{kg}$ in human newborns (12). Inasmuch as the blood volume per $\mathrm{kg}$ in human newborns is approximately 60 times greater than in chick embryos, GBSIG, $12 \mathrm{mg} / \mathrm{kg}(0.07$ $\mathrm{ml} / \mathrm{kg}$ of a $16.5 \mathrm{~g} \%$ preparation) would be roughly equivalent to $0.2 \mathrm{mg}$ of GBSIG that is protective in chick embryos against each of the four types tested.

Mice were protected against lethal IP challenges with types Ia, Ib. and II GBS by the IM administration of $0.5 \mathrm{mg}$ of GBSIG. In contrast. IM administration of $4.8 \mathrm{mg}$ of GBSIG failed to protect mice against IP challenges with type III GBS, and protection was observed only when GBSIG was administered simultaneously IP with III-Bell or when hyperimmune rabbit sera was given IM. The inability of IM-administered GBSIG to protect mice challenged IP with III-Bell may be explained by differences in murine resistance to type III GBS (10). Because the mean weight of the mice was $10 \mathrm{~g}$. the IM dose of GBSIG was $50 \mathrm{mg} / \mathrm{kg}$ or $0.3 \mathrm{ml} / \mathrm{kg}$ of a $16.5 \mathrm{~g} \%$ preparation for protection against types Ia, Ib, and II. The four-fold increase in GBSIG needed to protect mice compared to chick embryos probably reflects the differences in the route and timing of administration. Protection was more readily attained when $G G$ was mixed with bacteria immediately before IV injection into chick embryos than the IM administration of GG $24 \mathrm{hr}$ prior to IP bacterial challenge in mice.

These studies indicate that a hyperimmune globulin may be effective in preventing human infections with all of the GBS serotypes. Our results also suggest that. along with obvious theoretical advantages, an IV preparation would be superior, but enzyme-treated IV GG has not been approved for routine use. GBSIG is a potentially useful agent in preventing neonatal GBS infections, as well as a possible adjunct to antibiotic and supportive therapy of severe GBS infections. These studies demonstrating effectiveness in two animal models of GBS infections justify trials in human neonates.

\section{RTFEREN( IS ANI) NOTES}

1. Baker. ( J : Summary of the workshop on perinatal infections due to group B Sireponconcus. J. Infect. Dis.. 1.36: 137 (1977)

2. Baker. ('. J., Edwards. M. S., and Kasper, D. L.: Immunogenicity of polysaccharides from type III. group B Streptococcus. J. ('lin. Invest. 61: 1107 (1978)

3. Baker. (. J., and Kasper, D). L.: Immunological investigation of infants with septicema or meningitis due to group B Streptocoscus J Infect Dis Suppl. 1.36: S98 (1977).

4. Baker, ('. J., Kasper. D. L., Tager, I. B., Paredes, A., Alpert. S.. Mccormack. W M.. and Goroff. D.: Quantitative determination of antibody to capsular polysaccharide in infection with type III strains of group B Streptococcus. J. Clin. Invest.. 59: 810)(1977).

5. Baltimore. R. S., Kasper, D. L.. and Vecchitto, J. S.: Mouse protection test for group B Streptococcus type III. J. Infect. Dis., 140: 81 (1979).

6. Broughton. D. D., Mitchell. W. G.. Grossman. M.. Hadley, W. K.. and cohen. M. S.: Recurrence of group B streptococcal infection. J. Pediatr.. $8 \%: 18.3$ (1976).

7. Hemming. V. G.. Hall, R. T. Rhodes, P. G.. Shigeoka, A. O.. and Hill, H. R Assessment of group B streptococcal opsonins in human and rabbil serum by neutrophil chemiluminescence. J. (Clin. Invest., 5.8: 1379 (1976).

8. Kabat. E. A.: Kabat and Meyer's Fxperimental Immunochemistry. 2nd ed. (Charles (' Thomas. Springfield. IL. 1971).

9. Kretschmer. R. R.. and (joloff, S. P.: Immunological aspects of group B strep. tococcal infections. Infection, 6: 146 (1978).

10. Kretschmer. R. R.. Vogel. L. ('. Kelly. P.. Padnos, D.. Cioldman, M., and Ciotoff. 
S. P.: Mechanism of mouse resistance to group B. streptococci (GBS) type III (Ahstract). Seventh International Symposium on Streptococi and Streptocos(a) Diseases. No. 147 (1978).

11. Lancefield, R. C.. McC arthy. M.. and Everly. W. N.: Multiple mouse-protective antibodies directed against group B streptococci: special reference to antibodies effective against protein antigens. J. Exp. Med.. 142: 165 (1975).

12. Mollison. P. L. Veall. N. and Cutbush. M.: Red cell and plasma volume in newborn infants. Arch. Dis. (hild. 25: $242(1950)$

13. Romanoff. A. 1..: The Avian Embryo: Structural and Functional Development (The MacMillan Company. New York. 1960).

14. Shigeoka. A. O.. Hall. R. T.. and Hill, H. R.: Blood-transfusion in group-B streptociocal sepsis. Lancet. 1: $636(197 \mathrm{~K})$

15. Stewardson-Krieger. P. B.. Albrandt. K.. Nevin. T., Kretschmer. R. R., and (jotoff. S. P.: Perinatal immunity to group B $\beta$-hemolytic Streptococcus type la. J. Infect. Dis. I.in: $644(1977)$.

16. Stewardson-Krieger, P. B., and (jotoff. S. P.: Risk factors in early-onset neonatal group B streptococial infections. Infection. $6: 50(1978)$

17. Stiehm. E. R.: Standard and special human immune serum globulins as therapeutic agents. Pediatrics. 0.3: 301 (1979).

1x. Tieffenherg. J., Vogel. L.. Kretschmer. R. R.. Padnos. D., and Gotoff. S. P.: Chickem embryo model for type III group B beta-hemolytic streptococial septicemia. Infect. Immun.. 19: 481 (1978).
19. Truog. W. E.. Davis, R. F., and Ray, C. G.: Recurrence of group B streptocos infection. J. Pediatr., $84: 185(1976)$

20. Vogel. L. ( .. Kretschmer, R. R.. Boyer, K. M.. Padnos, D. M.. Gadzala. () and cotoff. S. P.: Prevalence of group B streptococcal antibody measured indirect immunofluorescence. Pediatr. Res. (Abstract), 1,3: 471) (1979).

21. Vogel. L. C.. Kretschmer, R. R.. Boyer, K. M.. Padnos. D. M.. Gadzala. C and (iotoff, S. P.: Human immunity to group B streptococci measured indired immunofluorescence: correlation with chick embryo protection. Infect. Dis.. 140: 682(1979).

22. Walker, S. H. Santos, A. Q.. and Quintero, B. A.: Recurrence of group B streptococcal meningitis. J. Pediatr. $84: 187$ (1976).

23. The authors thank Dr. Armando R. Orlina. Medical Director of the Mich Reese Hospital Blood Center, for his cooperation and Madeline Murphy 1 excellent secretarial support.

24. Reyuests for reprints should be addressed to: Samuel P. Gotoff. Department Pediatrics. Michael Reese Hospital and Medical (enter. 29th Street and El Avenue. (hicago. IL 606I0 (USA)

25. This research was supported by Public Health Service grants RO-1-HD-097 and RO-I-HD-11576 from the National Institute of (hild Health and Hum Development.

26. Received for publication April 23. 1979

27. Accepted for publication July 31. 1979. 